\title{
Volatile fatty acids and methane production in dairy cow ration based on protein-energy synchronization index with a meals protein source
}

\author{
Afduha Nurus Syamsi*1), and Lastriana Waldi ${ }^{2)}$ \\ ${ }^{1)}$ Faculty of Animal Science, Jenderal Soedirman University, Jl. DR. Soeparno Utara No.60, \\ Grendeng, Kec. Purwokerto Utara, Kabupaten Banyumas, Central Java, 53122, Indonesia \\ ${ }^{2}$ Dinas Pertanian Kabupaten Cirebon, Jl. Sunan Ampel No. 2, Sumber, Cirebon, Jawa Barat, \\ 45611, Indonesia
}

Submitted: 04 May 2020, Accepted: 03 June 2021

\begin{abstract}
The study was aimed to examine the production of volatile fatty acids (VFA) and methane $\left(\mathrm{CH}_{4}\right)$ in rations based on protein-energy synchronization index (PES) using different meals protein sources (MPS). The study was conducted experimentally with in vitro techniques. The factorial completely randomized design (CRD) was used to examine six types of treatment rations originating from a combination of 3 PES index and two types of MPS, each repeated four times so that there were a total of 24 experimental units. The results showed that the interaction of the SPE index had no significant effect on the production of partial VFA, but had a significant effect on the acetate: propionate (A: $\mathrm{P})$ ratio and $\mathrm{CH}_{4}$ production. The analysis of honestly significant different (HSD) results showed that the lowest A: P ratio and $\mathrm{CH}_{4}$ were found in $\mathrm{R} 1$. The orthogonal test shows that coconut and soybean meal had a quadratic effect on the $\mathrm{A}$ : $\mathrm{P}$ ratio and $\mathrm{CH}_{4}$. It concluded that the best PES index to optimize VFA and minimize $\mathrm{CH}_{4}$ production was at the index $0.6-0.61$ with soybean meal as protein source supplementation.
\end{abstract}

Keywords: Volatile fatty acids; Methane; Protein-energy synchronization index; Meal

*Corresponding Author: afduha.nurus.syamsi@unsoed.ac.id 


\section{INTRODUCTION}

Dairy cattle are part of the class of mammals and sub-orders of ruminants. That sub-order depends to a large extent on their energy needs in volatile fatty acids (VFA). The energy source is produced through the fermentation of feed in the reticulo-rumen (R-R) which is mediated by various rumen microorganisms. Rumen microorganisms will ferment most carbohydrates and proteins to produce energy, ammonia, and cofactors for growth. Therefore, the preparation of ruminant ration feed should be aimed at optimizing microbial protein synthesis (MPS) to maximize VFA production in the rumen.

Optimization of MPS in the rumen can be done by preparing rations based on the protein-energy synchronization (PES) index. This is a conceptual method for increasing MPS efficiency by regulating the degradation of protein and organic matter $(\mathrm{OM})$ in the rumen in a balanced way to optimize the supply of N-Protein and energy so that that rumen microorganisms can utilize both simultaneously (Seo et al., 2010). Its application can be made by compiling a ratio with an index between zero (0) to one (1). Rations with a PES index close to 1 , showing the availability of energy from $\mathrm{OM}$ and ammonia from protein increasingly synchronous (Sinclair et al., 1993). This concept is supported by Syamsi et al. (2017) and Waldi et al. (2017), which proves that MPS increases in rations compiled with PES index approaching 1.

Protein degradation in the rumen is also a major factor in the efficient use of protein in ruminants. Most degraded proteins must be maximally utilized for MPS. Protein degradation, which is too slow compared to OM, causes the accumulation of carbohydrate microbial cells because most of the energy cannot be utilized in MPS. While protein degradation is too fast, causing excess ammonia accumulation, and will be wasted (Kaswari, 2004). The use of protein is not only based on quantity but also degradation quality. Potential sources of protein used are coconut meals and soybean meals. Both have high protein content (sequentially $22.80 \%$ and $49.09 \%$ ) and good kinetic degradation with PES index values of 0.74 and 0.77 , respectively (Waldi et al., 2017).

The ratio with a higher PES index will result in a high total VFA and a low acetate: propionate (A: P) ratio (Seo et al., 2010). The low A: $\mathrm{P}$ ratio profile represents the potential for reducing energy wasted through methane (CH4). This impacts increasing propionate production as the primary energy source for ruminants (Mitsumori and Sun, 2008). Syamsi et al. (2018) in a previous study using legume protein sources in a ration based on the protein-energy synchronization index. These studies indicated that legumes with high protein and low antinutrient produced high VFA and low methane when arranged on a medium PES index ratio.

The use of protein sources is important to consider when preparing a ratio based on the PES index. Quality and degradability need to be balanced with energy sources of which the choice is more diverse and cheaper. Therefore, it is important to study the production of VFA and $\mathrm{CH} 4$ in rations compiled based on the PES index using different meals protein sources.

\section{MATERIALS AND METHODS Experimental Design}

The study is an experimental research using the In vitro method (Tilley and Terry, 1963). The rumen fluid of Friesian Holstein dairy cows was used as the material research, fed by elephant grass and commercial concentrates with a ratio of 60 : $40 \%$ during maintenance.

The study used a factorial Completely Randomized Design (CRD) (2x3), where factor A was two types of protein sources (coconut meal and soybean meal) and factor B was three levels of PES index $(0.5,0.6$, and 0.7). 
Table 1. The composition of each treatment ratio and its nutrition

\begin{tabular}{lcccccc}
\hline \multirow{1}{*}{ Feedstuffs } & $\mathrm{R} 1$ & $\mathrm{R} 2$ & $\mathrm{R} 3$ & $\mathrm{R} 4$ & $\mathrm{R} 5$ & $\mathrm{R} 6$ \\
\cline { 2 - 7 } & & & $\ldots \ldots \ldots \%$ & $\ldots \ldots \ldots . \ldots$ & & \\
\hline King grass & 60 & 60 & 58 & 60 & 60 & 59 \\
Coconut meal & $\mathbf{1 0}$ & $\mathbf{1 0}$ & $\mathbf{1 0}$ & 0 & 0 & 0 \\
Soybean meal & 0 & 0 & 0 & $\mathbf{1 0}$ & $\mathbf{1 0}$ & $\mathbf{1 0}$ \\
Dried Cassava & 3 & 5 & 21 & 3 & 5 & 20 \\
Rice bran & 10 & 4 & 2 & 10 & 4 & 2 \\
Pollard & 6 & 10 & 2 & 6 & 10 & 2 \\
Soyben dregs & 10 & 10 & 6 & 10 & 10 & 6 \\
Mineral & 1 & 1 & 1 & 1 & 1 & 1 \\
\hline Total & 100 & 100 & 100 & 100 & 100 & 100 \\
\hline PES index & 0.5 & 0.6 & 0.7 & 0.5 & 0.6 & 0.7 \\
\hline DM (\%) & 93.74 & 93.49 & 92.80 & 93.74 & 93.49 & 92.91 \\
CP (\%DM) & 11.91 & 12.09 & 10.2 & 14.50 & 14.67 & 12.87 \\
EE (\%DM) & 5.82 & 5.82 & 5.40 & 4.54 & 4.54 & 4.12 \\
CF (\%DM) & 23.78 & 23.16 & 21.70 & 23.20 & 22.60 & 21.41 \\
NFE (\%DM) & 48.14 & 49.23 & 53.80 & 47.30 & 48.42 & 52.52 \\
TDN \% & 59.99 & 60.21 & 61.60 & 60.40 & 60.65 & 61.75 \\
\hline
\end{tabular}

Notes: R: ration; PES: protein-energy Synchronization; DM: dry matter; CP: crude protein; EE: extract ether; CF: crude fiber; NFE: nitrogen free extract; TDN: total digestible nutrient

There are six treatment combinations, each treatment was repeated four times, and the total treatment was 24 . The treatment ratio was arranged based on Waldi et al. (2017) that is shown in Table 1.

\section{Determination of PES index of ration feed ingredients compiler}

The PES index of each feed ingredient is calculated based on the method developed by Hermon et al. (2008) for tropical feed ingredients. The first step is to measure protein and OM degradation of each feed ingredient in vitro. The time interval used to collect concentrate is $2,4,6,8,12,24,48$ hours, and for forage is $2,4,6,8,12,24,48$, 72 hours (modification based on Ørskov and Mcdonald (1979)).

After obtaining protein and $\mathrm{OM}$ degradation data at each collection time, a regression was performed to obtain the average value of protein and $\mathrm{OM}$ degradation per hour on each feed ingredient. The data is then entered into the PES index formula.

$$
\text { Synchronization Index }=\frac{20-\frac{\sqrt{\left(20-\frac{N}{O M} \text { hourly }\right)^{2}}}{24}}{20}
$$

Based on these formulas, it can be explained that $\mathrm{n}$ : observation time; $\mathrm{N}$ : hourly protein degradation; OM: hourly organic matter degradation; 20: digestibility standard for tropical feed ingredients $20 \mathrm{~g}$ $\mathrm{N}$-protein / $\mathrm{kg}$ OM digested in the rumen; 24: time of day. The index calculation results will always be between $0-1$. The PES index of each feed ingredient is then used to arrange the ratio using the trial and error method.

\section{Variable Analysis \\ Partial Volatile Fatty Acids (VFA)}

The partial VFA (acetate, propionate, butyrate) levels of rumen fluid was measured using the Goering and Van Soest (1970) method known as gas chromatography techniques. The initial stage is taking rumen fluid using a $4 \mathrm{ml}$ pipette, then centrifuged at $10,000 \mathrm{rpm}$ for 15 minutes. The supernatant is added as much as $2 \mathrm{ml}$ into a small plastic tube size of 
$5 \mathrm{ml}$. Add $30 \mathrm{mg}$ of 5-sulphosalicylic acid and then the solution is shaken, centrifuged at $3000 \mathrm{rpm}$ for 10 minutes at $4^{0} \mathrm{C}$, then filtered with millipore until clear liquid is obtained. A total of $1 \mu \mathrm{l}$ of clear liquid was injected into gas chromatography, which was previously injected with a standard VFA solution (acetate $52.54 \%$ molar, propionate $13.42 \%$ molar, n-butyrate $10.89 \%$ molar). The concentration in the sample is calculated using the following formula.

$$
\text { Partial VFA }=\frac{\text { sample area } \mathrm{x} \text { standard concentration } \mathrm{x} 1000}{\text { standard area } \mathrm{x} \text { molecular weight(C: } 2 / 3 / 4)}
$$

\section{Methane $\left(\mathrm{CH}_{4}\right)$}

Measurement of $\mathrm{CH} 4$ levels was carried out through a stikiometric model known as the $\mathrm{mM}$ formula and developed by Ørskov and Ryle (1990). The calculation formula is as follows.

$$
(\mathrm{mM})=0,5 \mathrm{a}-0,25 \mathrm{p}+0,5 \mathrm{~b} .
$$

Notes:

$$
\begin{array}{ll}
\mathrm{a} & =\text { asetate } \\
\mathrm{p} & =\text { propionate } \\
\mathrm{b} & =\text { butyrate }
\end{array}
$$

\section{RESULT AND DISCUSSION Volatile Fatty Acids (VFA)}

Volatile fatty acids (VFA) are fermented products produced from the fermentation process of carbohydrates in the rumen. This product is the main energy source for dairy cattle or ruminants in general. The highest levels of VFA found in the rumen are acetate $\left(C_{2}\right)$, propionate $\left(C_{3}\right)$ and butyrate $\left(\mathrm{C}_{4}\right)$, while the smallest amounts are formic acid, isocaproic acid, isobutyrate, isovalerate, and valerate. Each fatty acid is produced in a different process and is influenced by many factors. Factors that can affect VFA production are feed type, feed fermentability, and proteinenergy synchronization (PES) of feed (Seo et al., 2010).

The effect of ration preparation based on the PES index with different protein sources on partial VFA production can be seen in Table 2.

Table 2. The average of partial volatile fatty acids (VFA), A:P ratio, and methane for each treatment

\begin{tabular}{cllllll}
\hline \multirow{2}{*}{ Parameter } & \multicolumn{7}{c}{ Ration } \\
\cline { 2 - 7 } & $\mathrm{R} 1$ & $\mathrm{R} 2$ & $\mathrm{R} 3$ & $\mathrm{R} 4$ & $\mathrm{R} 5$ & $\mathrm{R} 6$ \\
\hline $\mathrm{C}_{2}(\mathrm{mM})$ & $36.70 \pm 4.49$ & $36.23 \pm 2.33$ & $35.32 \pm 0.63$ & $36.00 \pm 4.91$ & $35.05 \pm 5.53$ & $35.00 \pm 4.64$ \\
$\mathrm{C}_{3}(\mathrm{mM})$ & $20.52 \pm 1.88$ & $18.89 \pm 2.15$ & $18.76 \pm 0.72$ & $19.22 \pm 2.96$ & $19.57 \pm 2.52$ & $19.73 \pm 2.79$ \\
$\mathrm{C}_{4}(\mathrm{mM})$ & $1.03 \pm 1.02$ & $1.78 \pm 0.31$ & $1.97 \pm 0.25$ & $1.78 \pm 0.19$ & $1.90 \pm 0.35$ & $1.56 \pm 0.89$ \\
$\mathrm{~A}: \mathrm{P}$ ratio & $1.77^{\mathrm{b}} \pm 0.10$ & $1.94^{\mathrm{a}} \pm 0.04$ & $1.89^{\mathrm{ab}} \pm 0.10$ & $1.82^{\mathrm{ab}} \pm 0.08$ & $1.79^{\mathrm{ab}} \pm 0.02$ & $1.82^{\mathrm{ab}} \pm 0.07$ \\
$\mathrm{CH}_{4}(\mathrm{mM})$ & $23.39^{\mathrm{b}} \pm 1.05$ & $25.29^{\mathrm{a}} \pm 0.38$ & $24.90^{\mathrm{ab}} \pm 0.82$ & $24.27^{\mathrm{ab}} \pm 0.69$ & $24.00^{\mathrm{ab}} \pm 0.11$ & $24.21^{\mathrm{ab}} \pm 0.79$ \\
\hline Notes : $\quad \mathrm{R}=$ ration; $\mathrm{C}_{2}:$ asetate, $\mathrm{C}_{3}:$ propionate; $\mathrm{C}_{4}:$ butyrate; $\mathrm{CH}_{4}:$ methane; A:P: molar of acetate versus propionate; methan \\
\multicolumn{7}{c}{$(\mathrm{mM})=0.5 \mathrm{a}-0.25 \mathrm{p}+0.5 \mathrm{~b} ;{ }^{\text {ab }}$ Different superscripts on the same line, show no difference at P<0.05 }
\end{tabular}

The results of an analysis of variance showed that the interaction between protein sources with PES index, type of protein source, and PES index level had no significant effect $(\mathrm{P}>0.05)$ on partial VFA $\left(\mathrm{C}_{2}, \mathrm{C}_{3}\right.$, and $\left.\mathrm{C}_{4}\right)$. It is because the proportion of meals protein source does not differ in all treatments. Each treatment received $10 \%$ of meal protein supplementation. Although both coconut meal and soybean meal have pretty different nutritional levels, their roles in each treatment produce nutritional value which is not much different. Syamsi et al. (2018) state that VFA production can be influenced by differences in NFE and TDN levels in each treatment ration. Table 1 
shows that TDN in each treatment was not much different (59.99-61.75\%). It shows that the chance of the amount of food digested evenly in each treatment. Besides, the variation of NFE levels in each treatment was also not too different (48.14-53.80\%), so that the molar of partial VFA was also not significantly different. The results of partial VFA studies did not show significant variations. However, the proportion of each partial VFA molar is quite good. According to Chiba (2014), dairy rations containing most fiber sources generally produce $65 \%$ acetate, $20 \%$ propionate, and $12 \%$ butyrate. The average production of $\mathrm{C}_{2}, \mathrm{C}_{3}$, and $\mathrm{C}_{4}$ in all treatment rations in a sequence that is $35.72 \mathrm{mM}, 19.44 \mathrm{mM}$, and $1.81 \mathrm{mM}$. The results was calculated as a percent in a sequence, namely $62.69 \%, 34.13 \%$, and $3.18 \%$. The percentage of $\mathrm{C}_{2}$ appears to be lower than the standard, but $\mathrm{C}_{3}$ is higher. The data shows good results because a decrease in $\mathrm{C}_{2}$ and an increase in $\mathrm{C}_{3}$ will reduce the $\mathrm{A}: \mathrm{P}$ ratio. The broader impact is on the potential reduction in methane gas production in rumen fermentation.

\section{A:P Ratio and Methane (CH4) Production}

The study produced a fairly low A:P ratio and methane, namely 1.77-1.94 and 23.39-25.29 mM, respectively. The results of the analysis of variance showed that the interaction between protein sources and the
PES index had a significant effect $(\mathrm{P}>0.05)$ on the A:P ratio and methane. The honestly significant difference (HSD) showed that the highest $A: P$ ratio and methane production are in $\mathrm{R} 2$ and the lowest in $\mathrm{R} 1$, but they are not different from R3, R4, R5, and R6. It is because the R1 has the highest propionate production compared to the others. Mitsumori and Sun (2008) stated that the increased propionate production would lead to high using of $\mathrm{H}_{2}$ through the succinate pathway. This causes a decrease in $\mathrm{H}_{2}$ supply in the methanogenesis pathway, resulting in decreased methane production. The fiber and NFE content is not significantly different in each treatment. It causing the results to be not different in other treatments. Orthogonal polynomial test showed that the interaction between coconut meal with PES index affects quadratically to $\mathrm{A}: \mathrm{P}$ ratio with the equation $\mathrm{y}=-2.42+13.94 \mathrm{X}-11.12 \mathrm{X} 2 ; \mathrm{r}^{2}=0.85$. Interaction between soybean meal with PES index to A:P ratio affects quadratically with equation $\mathrm{y}=3.14-4.5 \mathrm{X}+375 \mathrm{X} 2 ; \mathrm{r}^{2}=0.81$. The interaction between coconut meal and PES index affects quadratically on methane production with the equation $\mathrm{y}=-20.23+$ $144.19 \mathrm{X}-113.88 \mathrm{X} 2 ; \mathrm{r}^{2}=0.85$. The interaction between soybean meal with PES index affects quadratically on methane production with the equation $\mathrm{y}=32.74$ $28.8 \mathrm{X}+23.75 \mathrm{X} 2 ; \mathrm{r}^{2}=0.85$ (Figure 1).
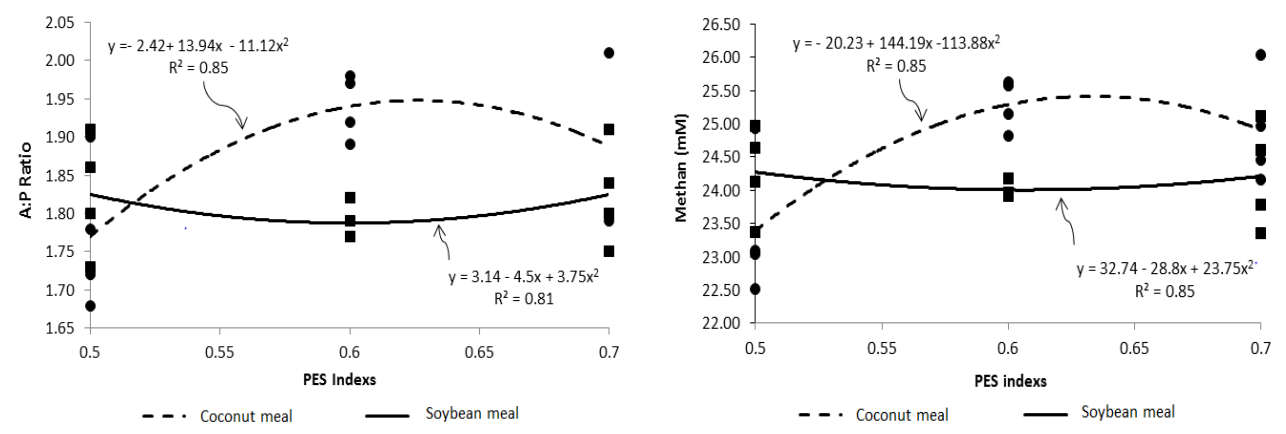

Figure 1. The effect of the interaction between the meals protein source with the PES index to the A:P ratio graph (left) and methane production graph (right)

Coconut meal yields the lowest A:P ratio at the index of 0.5 , then increases to the index of 0.63 , and decreases thereafter or with a maximum point of $\mathrm{P}(0.63 ; 1.95)$. In contrast, soybean meal produces an A:P ratio that decreases from index 0.5 to index 
0.60 , then increases thereafter or with a minimum point of $\mathrm{P}(0.60 ; 1.79)$. A similar graph is also shown in methane production, which is the maximum point of coconut meal at $\mathrm{P}(0.63 ; 25.41)$, then the minimum point for soybean meal at $\mathrm{P}(0.61 ; 24.00)$. Gulmez and Turkmen (2007) explain that the $\mathrm{A}: \mathrm{P}$ ratio is very closely related to methane production, so that there is a tendency to increase and decrease the same graph in each treatment. Cabrita et al. (2006) added that protein and ration energy synchronization gave quite varied results. The synchronization time at each index is not always the same because it is influenced by the type of feed and the performance of rumen microorganisms. Syamsi et al. (2019) also added that the proportion of feed ingredients and the timing of rumen fluid collection are crucial to the analysis results.

The results showed that the average of $\mathrm{A}: \mathrm{P}$ ratio was classified at a low level, namely between $1.77-1.94$. This is also in line with the research of Syamsi et al. (2018), which shows that the ration based on the PES index produces a level of A:P ratio between 1.68-1.95. These results are smaller than Gulmez and Turkmen (2007), which is between 3.31-4.21. Similar results were also shown in the relatively low $\mathrm{CH}_{4}$ production, which was between 23.39-25.29 mM. Tapio et al. (2017) and Syamsi et al. (2020) explain that methane is wasted energy potential with a percentage reaching $2-12 \%$. Therefore, a good ratio shows a high VFA production and produces a minimum of $\mathrm{CH}_{4}$.

Figure 1 showed that the average A:P ratio and $\mathrm{CH}_{4}$ in the ratio with soybean meal is lower than coconut cake until the last index. Waldi et al. (2017) state that soybean meal and coconut meal have a PES index which is equal to level, however, the quality of protein in soybean meal is better. Some studies explain that soybean meal has a complete composition of amino acids to help rumen fermentability. Therefore, the use of soybean meal as a source of protein has a broad impact, not only on the provision of ammonia for microbes but is needed in other fermentation processes.

\section{CONCLUSIONS}

The study concluded that the best protein-energy synchronization index to optimize the production of volatile fatty acids and minimize methane production was at an index of 0.6-0.61 with a soybean meal as a source of protein supplementation.

\section{REFERENCES}

Cabrita, A. R. J., Dewhurst, R. J., Abreu, J. M. F., \& Fonseca, A. J. M. (2006). Evaluation of the effects of synchronising the availability of $\mathrm{N}$ and energy on rumen function and production responses of dairy cows a review. Animal Research, 55(1), 124. https://doi.org/10.1051/animres:2 005045

Chiba, L. I. (2014). Rumen Microbiology and Fermentation. In Animal Nutrition Handbook.

Engelking, L. R. (2015). Overview of Carbohydrate Metabolism. In Textbook of Veterinary Physiological Chemistry (pp. 136-140). Elsevier. https://doi.org/10.1016/B978-0-12-39 1909-0.50021-9

Goering, H. K., \& Soest, P. J. Van. (1970). Forage Fiber Analysis. In Agricultural Handbook (379th ed.). United States Department of Agriculture.

Gulmez, B. H., \& Turkmen, I. I. (2007). Effect of starch sources with different degradation rates on ruminal fermentation of lactating dairy cows. Revue de Medecine Veterinaire, 158(2), 92-99.

Hermon, M., Suryahadi, K. G., Wiryawan, \& Hardjosoewignjo, S. (2008). Nisbah sinkronisasi suplai N-Protein dan Energi dalam rumen sebagai basis formulasi ransum ternak ruminansia. Media Peternakan, 31(3), 186-194.

Kaswari, T. (2004). Synchronization of Energy and Protein Supply in The Rumen of Diary Crows (3017th ed.). Göttingen. 
Mitsumori, M., \& Sun, W. (2008). Control of rumen microbial fermentation for mitigating methane emissions from the rumen. Asian-Australasian Journal of Animal Sciences, 21(1), 144-154. https://doi.org/10.5713/ajas. 2008.r01

Ørskov, E. R., \& McDonald, I. (1979). The estimating of protein degradability in the rumen from incubation measurement weighted activating to rate of passage. The Journal of Agrculture Science, 92(2), 499-503.

Ørskov, E. R., \& Ryle, M. (1990). Energy Nutrition in Ruminants. Elsevier Science Publishers Ltd.

Seo, J. K., Yang, J., Kim, H. J., Upadhaya, S. D., Cho, W. M., \& Ha, J. K. (2010). Effects of synchronization of carbohydrate and protein supply on ruminal fermentation, nitrogen metabolism and microbial protein synthesis in holstein steers. AsianAustralasian Journal of Animal Sciences, 23(11), 1455-1461. https:// doi.org/10.5713/ajas.2010.10247

Sinclair, L. A., Garnsworthy, P. C., Newbold, J. R., \& Buttery, P. J. (1995). Effects of synchronizing the rate of dietary energy and nitrogen release in diets with a similar carbohydrate composition on rumen fermentation and microbial protein synthesis in sheep. The Journal of Agricultural Science, 124(3), 463472. https://doi.org/10.1017/S002185 9600073421

Syamsi, A. N., Waldi, L., Widodo, H. S., \& Harwanto. (2019). Branched chain volatile fatty acids profile of rumen fluids suplemented by different meal protein sources and protein-energy synchronization index. IOP Conference Series: Earth and Environmental Science, 372(1), 012060. https://doi.org/10.1088/17551315/372/1/012060

Syamsi, A.N, Widodo, H. S., Astuti, T. Y., Soediarto, P., \& Subagyo, Y. (2020). Potensi Produksi Energi Ransum
Berbasis Indeks Sinkronisasi ProteinEnergi dengan Suplementasi Leguminosa Berbeda. Prosiding Seminar Nasional Fakultas Agorindustri Tahun 2020: Peningkatan Daya Saing Melalui Perbaikan Mutu Produk Dalam Rangka Pembangunan Pertanian Di Era Industri 4.0.

Syamsi, Afduha Nurus, Astuti, T. Y., \& Soediarto, P. (2018). Volatile fatty acids and methane profile of dairy cattle ruminal fluid was gived legumes in ration based on synchronization protein-energy index. Buletin Peternakan, 42(4), 283-289. https:// doi.org/10.21059/buletinpeternak.v42 i4.33074

Syamsi, A. N, Suhartati, F. M., \& Suryapratama, W. (2019). Pengaruh daun turi (Sesbania grandiflora) dan lamtoro (Leucaena leucocephala) dalam ransum sapi berbasis indeks sinkronisasi protein - energi terhadap sintesis protein mikroba rumen. Pastura, 6(2), 47-52. https://doi.org/ 10.24843/Pastura.2017.v06.i02.p01

Tapio, I., Snelling, T. J., Strozzi, F., \& Wallace, R. J. (2017). The ruminal microbiome associated with methane emissions from ruminant livestock. Journal of Animal Science and Biotechnology, 8(1), 1-11. https:// doi.org/10.1186/s40104-017-0141-0

Tilley, J. M. A., \& Terry, R. A. (1969). The relationship between the soluble constitutent herbage and their dry matter digestibility. Grass and Forage Science, 24(4), 290-295. https://doi.org/ 10.1111/j.1365-2494.1969.tb01083.x

Waldi, L. (2017). Pengaruh penggunaan bungkil kedelai dan bungkil kelapa dalam ransum berbasis indeks sinkronisasi energi dan protein terhadap sintesis protein mikroba rumen sapi perah. Journal of Livestock Science and Production, 1(1), 1-12. https://doi.org/10.31002/jalspro.v1i1. 446 